University of Nebraska - Lincoln

DigitalCommons@University of Nebraska - Lincoln

BREEDING BIOLOGY AND SUCCESS OF A REINTRODUCED POPULATION OF THE CRITICALLY ENDANGERED PUAIOHI (MYADESTES PALMERI)

\author{
Erik J. Tweed \\ Jeffrey T. Foster \\ Bethany L. Woodworth \\ William B. Monahan \\ Jherime L. Kellerman
}

See next page for additional authors

Follow this and additional works at: https://digitalcommons.unl.edu/usgsstaffpub

Part of the Geology Commons, Oceanography and Atmospheric Sciences and Meteorology Commons, Other Earth Sciences Commons, and the Other Environmental Sciences Commons

This Article is brought to you for free and open access by the US Geological Survey at DigitalCommons@University of Nebraska - Lincoln. It has been accepted for inclusion in USGS Staff -- Published Research by an authorized administrator of DigitalCommons@University of Nebraska - Lincoln. 


\section{Authors}

Erik J. Tweed, Jeffrey T. Foster, Bethany L. Woodworth, William B. Monahan, Jherime L. Kellerman, and Alan Lieberman 


\title{
BREEDING BIOLOGY AND SUCCESS OF A REINTRODUCED POPULATION OF THE CRITICALLY ENDANGERED PUAIOHI (MYADESTES PALMERI)
}

\author{
Erik J. Tweed, ${ }^{1,2}$ Jeffrey T. Foster, ${ }^{1,2,4}$ Bethany L. Woodworth, ${ }^{1,5}$ \\ William B. Monahan, ${ }^{1,2,6}$ Jherime L. Kellerman, ${ }^{1,2,7}$ and Alan Lieberman ${ }^{3,8}$ \\ ${ }^{1}$ U.S. Geological Survey, Pacific Island Ecosystems Research Center, P.O. Box 44, Hawaii National Park, Hawaii 96718, USA; \\ ${ }^{2}$ Pacific Cooperative Studies Unit, Department of Botany, University of Hawaii, Honolulu, Hawaii 96822, USA; and \\ ${ }^{3}$ Zoological Society of San Diego, Hawaii Endangered Bird Conservation Program, P.O. Box 39, Volcano, Hawaii 96785, USA
}

AвSTRACT. - The ultimate success of reintroduction programs for endangered species depends on the ability of reintroduced animals to breed in the wild. We studied the nesting success and breeding biology of a reintroduced population of Puaiohi (Myadestes palmeri) on the island of Kaua'i, Hawaii. Thirty-four captive-bred Puaiohi were released into the Alaka'i Swamp in 1999-2001 and monitored using radiotelemetry. Ten females and two males paired with wild and other released birds, including one polygynous trio. From March to September, 31 nests were built. Mean clutch size was 2.0 eggs, daily nest survival was $0.97 \pm 0.01$ (mean $\pm \mathrm{SE}$ ) and overall nest success was $0.40 \pm 0.02$. We confirmed predation, most probably by rats (Rattus spp.), as the greatest cause of nest failure, occurring at $38 \%$ of active nests with known fates, and causing the death of two nesting adult females. Ground-based rodent control proved ineffective at protecting nest attempts. Successful nests fledged an average of 1.4 young each $(n=10)$, and $85 \%$ of fledglings survived at least two weeks. Importantly, breeding behavior and success were comparable to those of wild Puaiohi. This is the first record of breeding in the wild from captive-bred endangered Hawaiian passerines. The ability of captive-bred Puaiohi to survive and breed successfully in the wild bodes well for future releases of this and other endangered passerines, but high predation rates on nests and nesting females highlights the importance of maintaining and restoring safe habitat for recovery. Received 15 February 2005, accepted 5 October 2005.

Key words: captive breeding, Hawaiian birds, Myadestes palmeri, nest success, Puaiohi, reintroduction.

Biología y Éxito Reproductivo de una Población Reintroducida de Myadestes palmeri, una Especie en Peligro Crítico

Resumen.-El éxito final de los programas de reintroducción para especies en peligro depende de la habilidad de los animales reintroducidos de reproducirse en estado silvestre. Estudiamos el éxito de nidificación y la biología reproductiva de

\footnotetext{
${ }^{4}$ Present address: Program in Ecology and Evolutionary Biology, 606 East Healey Street, University of Illinois, Champaign, Illinois 61820, USA.

${ }^{5}$ Address correspondence to this author. Present address: 25 Ocean View Avenue, South Portland, Maine 04106, USA. E-mail: bethany_woodworth@usgs.gov

${ }^{6}$ Present address: Museum of Vertebrate Zoology, 3101 Valley Life Sciences Building, University of California, Berkeley, California 94720, USA.

${ }^{7}$ Present address: Natural Resources Wildlife, Humboldt State University, 1303 Sunset Avenue, Arcata, California 95521, USA.

${ }^{8}$ Present address: San Diego Zoo, P.O. Box 120551, San Diego, California 92112, USA.
} 
una población reintroducida de Myadestes palmeri en la Isla de Kauai, Hawai. Treinta y cuatro individuos criados en cautiverio fueron liberados en Alakai Swamp entre 1999 y 2001, los cuales fueron monitoreados usando radio telemetría. Diez hembras y dos machos se emparejaron con aves silvestres y otras aves liberadas, incluyendo un trío polígino. Desde marzo a septiembre 31 nidos fueron construidos. El tamaño promedio de la nidada fue de 2.0 huevos, la supervivencia diaria de los nidos fue de $0.97 \pm 0.01$ (media $\pm E E$ ) y el éxito de nidificación total fue de $0.40 \pm 0.02$. Confirmamos eventos de depredación, probablemente por ratas (Rattus spp.), como la mayor causa de fracaso de los nidos, ocurriendo en el 38\% de los nidos activos con destino conocido y causando la muerte de dos hembras adultas nidificantes. Las estrategias de control de los roedores en el suelo fueron ineficientes para proteger los intentos de nidificación. Los nidos exitosos produjeron un promedio de 1.4 volantones cada uno $(n=10)$ y el $85 \%$ de los volantones sobrevivió al menos dos semanas. El comportamiento y el éxito reproductivo fueron comparables a los de los individuos silvestres de M. palmeri. Este es el primer registro de reproducción silvestre de paseriformes hawaianos criados en cautiverio. La habilidad de los individuos de M. palmeri criados en cautiverio de sobrevivir y de criar con éxito, promete buenos augurios para la liberación de esta y de otras especies en peligro. Sin embargo, las altas tasas de depredación de los nidos y de las hembras nidificantes subrayan la importancia de mantener y restaurar hábitat seguro para su recuperación.

Reintroductions of endangered species to formerly occupied habitat have helped restore declining bird populations worldwide (e.g., Rudolph et al. 1992, Sanz and Grajal 1998, Armstrong et al. 1999) and are part of a conservation strategy to save endangered Hawaiian birds (U.S. Fish and Wildlife Service [USFWS] 2003). The ultimate success of reintroductions is critically dependent on the ability of the released animals to establish self-sustaining populations in the release habitat, which involves both short-term (survival during establishment phase, fidelity to release area) and long-term processes (long-term survival and breeding success) (Armstrong et al. 1999). Failure of captivebred and released animals to breed successfully in the wild may be the result of poor behavioral adjustment, lack of suitable breeding partners, genetic abnormalities (inbreeding effects), or poor ecological conditions. Demographic data such as breeding success are essential in determining the mechanisms responsible for reintroduction success or failure (Armstrong et al. 2002) and adapting subsequent releases. Furthermore, when properly designed, release programs may provide critical insights into local limiting factors and suggest further recovery actions (Scott and Carpenter 1987).

The Hawaiian avifauna has suffered tremendous losses resulting from habitat alteration, introduced mammalian predators, and avian disease (Ralph and van Riper 1985, van Riper and Scott 2001). More than half of the endemic avifauna of the Hawaiian Islands, roughly 74 species, has become extinct, and most of the remaining native land birds are threatened or endangered (Scott et al. 2001). On the island of Kaua 'i, disease and habitat loss have ravaged most lowland forest bird populations, and the remaining birds are restricted primarily to the montane areas of the Alaka'i Swamp and Kōke'e State Park (Fig. 1). Captive breeding and release may be necessary for the continued survival of some species (USFWS 2003).

In 1995, the rediscovery of a small breeding population of the critically endangered Puaiohi (Myadestes palmeri) in the remote Alaka 'i Swamp raised hopes for the recovery of the species. Work immediately commenced on study of Puaiohi breeding biology in the wild and establishment of a captive breeding population for subsequent reintroduction. The Puaiohi, one of the most endangered Hawaiian forest birds, is now known to number only 300-500 individuals in the entire Alaka'i Wilderness Preserve, Kaua'i, and fully $75 \%$ of Puaiohi are restricted to an area $<10 \mathrm{~km}^{2}$ in the remote reaches of the swamp (Snetsinger et al. 1999). Stochastic events threaten the Puaiohi; hurricanes struck Kaua'i in 1982 and 1992, severely damaging habitat and possibly causing the extinction of several endangered forest birds (Pratt 1994, Foster et al. 


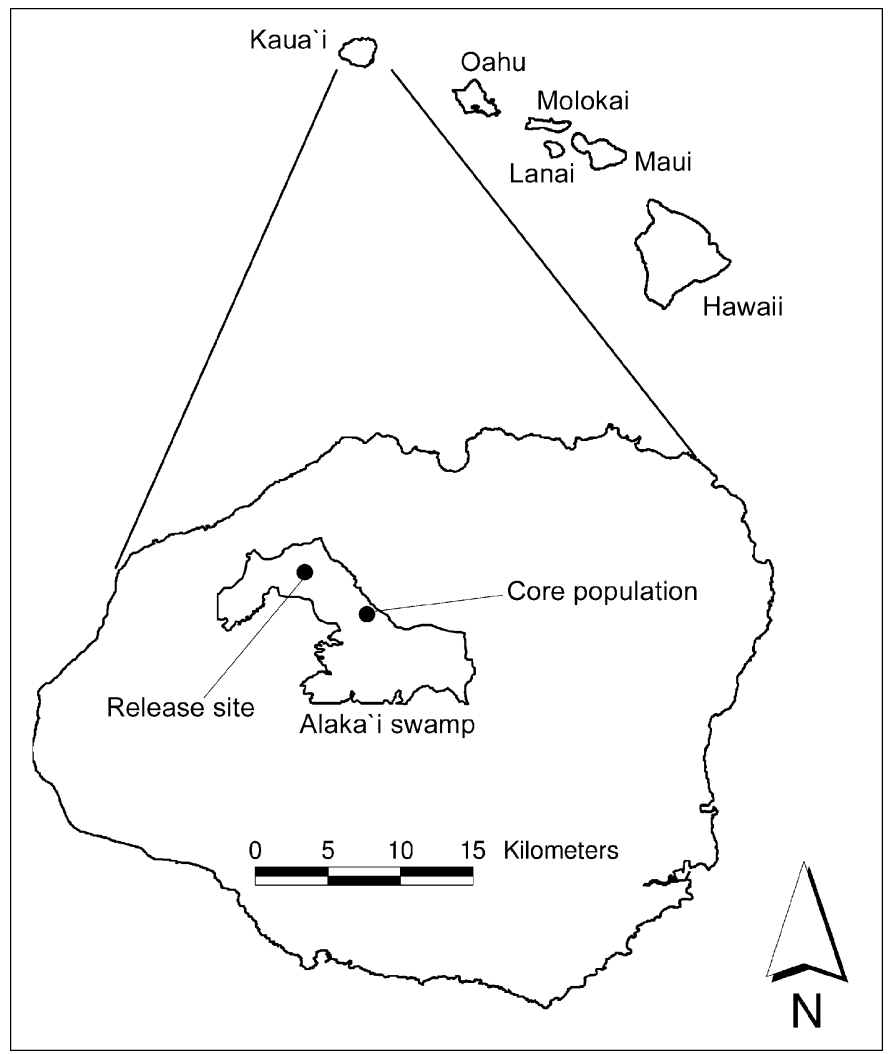

Fig. 1. Map of Kaua'i Island showing the boundaries of the Alaka'i Wilderness Preserve and the locations of the release area and wild ("core") populations.

2004). With the extinction of its larger congener, the Kāma'o ( $M$. myadestinus; Reynolds and Snetsinger 2001), the Puaiohi became the only remaining native frugivore in the Alaka'i ecosystem and one of only two extant members of an original complex of five Hawaiian thrushes (Pratt 1982). Its perilously small population size, and the disappearance of five other endangered species on Kaua' $i$ within the past 30 years, has made it a priority for conservation.

Several lines of evidence suggest that reintroductions could aid in the recovery of this species. First, many areas of the Alaka'i Swamp devastated by the last two hurricanes are now recovering, and the Puaiohi's main food plants appear to be abundant (U.S. Geological Survey [USGS] unpubl. data). Second, there is limited evidence that both the Puaiohi and the closely related 'Ōma'o ( $M$. obscurus) may be developing resistance to avian malaria (Plasmodium relictum; Atkinson et al. 2001). Finally, Puaiohi demonstrate high fecundity but limited dispersal in the wild (Snetsinger et al. 2005), which suggests that low dispersal might slow the species' re-establishment into formerly occupied habitat. Thus, recovery efforts have focused on expanding the limited range of the species by re-establishing breeding populations where the species is absent or present in low numbers.

Beginning in 1996, a three-year study of the breeding ecology of wild Puaiohi was conducted in the "core" population in the Mohihi stream drainage (Fig. 1; Snestinger et al. 2005). Simultaneously, research was begun to develop captive breeding, rearing, and reintroduction techniques with the non-endangered 'Ōma'o as a surrogate for the endangered Puaiohi (Kuehler et al. 2000, Fancy et al. 2001). The success of these efforts paved the way for establishment of a captive breeding and reintroduction program for Puaiohi. Beginning in 1996, The Peregrine Fund (TPF) and Zoological Society of San Diego (ZSSD) 
established a captive breeding flock of Puaiohi at the Keauhou Bird Conservation Facility (see Kuehler et al. [2000] for details of rearing and releasing methodology). By 1999, only five years after the rediscovery of a wild population, the first captive-bred Puaiohi were released into formerly occupied habitat in the Alaka'i Swamp (Kuehler et al. 2000, Tweed et al. 2003).

Survival rates of released birds during the establishment phase was encouraging: all 14 birds released in 1999 survived the first eight weeks in their new habitat (Tweed et al. 2003). Six of the released birds (43\%) remained in the target drainage to breed, and the others dispersed $\leq 4 \mathrm{~km}$ to find mates or breeding territories elsewhere (Tweed et el. 2003). Over the subsequent two years, an additional 20 birds were released in the Kawaikōī Stream, for a total of 34 released birds ( 21 females, 13 males).

To establish a new population, it is essential for released birds to not only survive during establishment phase and settle in the target area, but to pair and nest successfully in the release habitat and, furthermore, to recruit sufficient young to balance mortality. We monitored birds following release using radiotelemetry to examine the reproductive potential of captive-reared Puaiohi in this habitat. Specifically, we sought to (1) determine whether captive-reared birds were capable of pairing and breeding in the wild, (2) document nesting behavior and success of reintroduced birds, (3) compare reproductive parameters between the released population and a wild population in the Mohihi drainage of the Alaka'i plateau studied by Snetsinger et al. (2005), and (4) determine factors limiting population growth in the newly established population. The results have implications not only for Puaiohi recovery but also for the success of captive breeding and reintroduction programs for passerine birds throughout Hawaii and elsewhere.

\section{Methods}

Study area and species. - The release was conducted in the Kawaikōi Stream drainage on the northwest edge of the Alaka'i Swamp (Fig. 1; $\left.22^{\circ} 09^{\prime} \mathrm{N}, 159^{\circ} 37^{\prime} \mathrm{W}\right)$. The swamp, actually a wet montane rainforest on a plateau at $\sim 1,200 \mathrm{~m}$, is dominated by 'ōhi'a (Metrosideros polymorpha) and a dense understory of predominantly native shrubs and ferns. Rainfall at the release site averages 3-4 m annually, and reaches $13 \mathrm{~m}$ at the eastern edge of the swamp (Giambelluca et al. 1986). The Alaka'i Wilderness Preserve $(3,644 \mathrm{ha})$ is protected and managed by the Hawaii Division of Forestry and Wildlife (DOFAW). A network of deep and meandering streams drains the plateau and has created suitable streamside nesting habitat for Puaiohi, a ravine specialist and cliff-nester. The release site was selected on the basis of several criteria, including historic range, habitat quality, disease vectors, predators, land ownership and protection, and access (Tweed et al. 2003).

The Puaiohi, or small Kaua'i thrush, is a medium-sized (37.0-43.0 g) solitaire-like thrush that feeds on fleshy native fruits, insects, snails, and other invertebrates. Puaiohi nest in cavities or shelves on cliff faces in narrow ravines, and nest sites may be limiting in some habitats. Birds breed from March or April to June, but, with favorable weather, they nest into September. Females build the nest and incubate the twoegg clutch, and males and females together feed nestlings. Pairs readily and quickly renest after nest loss or fledging of young, renesting $\leq 5$ times in the wild; they have a propensity to double- or triple-brood in years with long breeding seasons (Snetsinger et al. 1999).

Release and monitoring.-The Peregrine Fund and ZSSD released a total of 34 captive-bred Puaiohi into the lower Kawaikōi drainage in January and February 1999 (8 females, 6 males), 2000 (1 male, 4 females), and 2001 (9 females, 6 males). Birds ranged in age from 5 to 14 months. Birds were held on site in predator-proof hacktowers (aviaries atop scaffolding) or howdy cages for 6-14 days before release to allow them to acclimate to local conditions. After release, birds were provided with supplemental food ad libitum at the hacktower for $\leq 30$ days. For details of rearing and release methodology, see Kuehler et al. (2000).

Released birds were uniquely color-banded and fitted with lightweight radiotransmitters weighing $<5 \%$ of their body weight (model BD-2G; frequency 164.2-165.0 MHz; battery life $\sim 8$ weeks; Holohil Systems, Carp, Ontario) using an elastic figure- 8 harness (Rappole and Tipton 1991). Breeding birds were monitored from January through September 1999 and from January through June 2001 (because of limited funding, no breeding data were collected in 2000, when only five birds were released).

Nest success. - Nests were located using behavioral cues of the pair. Nests with easy 
access were monitored every 1-4 days, and more remote nests (requiring extensive hiking over rugged terrain) were monitored every 4-10 days. Nest contents were determined using a mirror and pole, or through adult and nestling behavior for inaccessible nests. Transition dates (e.g., egg laying, start of incubation, hatching, and fledging) were observed directly or calculated from the beginning of a known stage in the nesting cycle. Nesting success, including daily nest survival rates, were estimated using the Mayfield (1961, 1975) method. More sophisticated models of nest success (e.g., logistic-exposure model of Shaffer [2004]) that incorporate variables potentially affecting nesting success were not appropriate, because of small sample size. For Mayfield estimates, we assumed an incubation period of 13.3 days and an 18.3-day nestling period (Snetsinger et al. 2005, present study). Nestlings were colorbanded at 11-12 days of age, and fledglings (which cannot fly well and remain close to the ground for several days after fledging) were captured by hand and banded. In case of adult or nestling death, carcasses were necropsied by wildlife veterinarian Dr. Thierry Work (USGS) to determine cause of death. We concluded that failure was attributable to rat predation if any of the following applied: (1) necropsies of intact nestlings showing trauma from predation; (2) observations of healthy female and nestlings on the afternoon before the predation event, reducing likelihood that birds had been scavenged after dying of natural causes; (3) discovery of rat feces in nests after predation or of bird carcasses dragged into areas accessible only to rats.

Predator assessment and control.-To protect birds in the hacktowers and during post-release visits to feeders, we controlled rats (Rattus spp.) in a $300 \times 300 \mathrm{~m}$ grid surrounding each hacktower for one to two months before each release, following methods developed by Nelson et al. (2002). Rodents were controlled using a combination of baiting with $0.005 \%$ Diphacinone rodenticide in tamperproof bait stations and coconut-baited snap-traps placed every $50 \mathrm{~m}$ throughout the grid. Diphacinone is an anticoagulant poison that is most effective if consumed in discrete doses over several days (Tobin 1992), and we replenished or replaced bait throughout the study period as needed. Snap-traps were discontinued after the first release of Puaiohi each season to prevent accidental captures of birds.
To determine the effectiveness of control, we assessed pre- and postcontrol rodent abundances using Census blocks (Zeneca Professional Products, Wilmington, Delaware) secured at each station with wire flagging and exposed for two to three days. Census blocks are a nontoxic formulation of cereal meal, wax, and attractants, which indicate rodent presence or absence by chew marks left on the blocks. Rodent control resulted in a 55\% decrease in rat activity surrounding the hacktowers (USGS unpubl. data).

Because of the endangered status of this species, we also protected individual nests. We placed one to four tamper-proof bait stations containing $8 \mathrm{oz}$. of $0.005 \%$ diphacinone rodenticide within $10 \mathrm{~m}$ of 12 active nests. An additional 16 active nests (12 with known fates) remained unprotected because regulations prohibit poison bait use within $5 \mathrm{~m}$ of water. In addition to bait, each protected nest received three snap traps within $10 \mathrm{~m}$ of the nest. Traps were placed within 1-m-long PVC tubes to prevent bird entrapment while allowing rat access.

\section{Results}

Overall, 91\% of released birds survived to independence (defined as 30 days post-release; $n=34$ ), and $75 \%$ of birds reaching independence survived the subsequent 50 days (e.g., from 30 to 80 days post-release; $n=12$ ). Two females were depredated on their nests by rats, one female was taken by a Pueo (Asio flammeus sandwichensis, the endemic subspecies of Short-eared Owl), and three died of unknown causes.

Breeding behavior.-All birds monitored throughout the breeding season following their release paired and had active nests $(n=10$ females and 2 males). We observed two captivecaptive pairs, six captive-bred females paired with wild males, and one captive-bred male that paired and nested simultaneously with two captive-bred females. One male was observed in more than one year; this male was polygynously mated in 1999, and monogamously paired in 2001. This is the first documented observation of polygyny in a Hawaiian thrush. No dispersing males were confirmed breeding (because of distance or inaccessibility of home ranges), but all these males appeared to have settled in areas containing wild Puaiohi.

We found 31 nests of 10 captive-bred females (21 in 1999, 10 in 2001), 23 nests belonging to 
8 monogamously mated females, and 8 nests belonging to 2 polygynously mated females. Of these 31 nests, 28 became active, and nest fate was known for 24 . We observed nests for totals of $47 \mathrm{~h}$ at 11 nests during building, $102 \mathrm{~h}$ at 17 nests during incubation, and $131 \mathrm{~h}$ at 17 nests during brooding.

In 1999, the breeding season (initiation of first clutch to initiation of last clutch) was 130 days, from 25 March to 12 August, and all eight of the captive-bred females that were monitored that year were nesting by early April. Remarkably, one female began collecting nesting material inside the hacktower within two weeks of her release. In 2001, the earliest eggs were laid on 19 March (end of breeding season unknown, but extended beyond the end of field work in June).

Captive-bred Puaiohi constructed nests on shelves in cliff faces $(n=23)$ and in 'ōhi'a trees $(n=8)$. Tree nest sites were in recesses of horizontal limbs, tree cavities, or exposed roots of blown-down trees. Captive-bred Puaiohi built a significantly higher proportion of their nests in trees than wild birds in the Mohihi drainage: 8 of $31(26 \%)$ nests were placed in 'ōhi'a trees during this study, compared with 5 of $93(5 \%)$ wild birds' nests in Snetsinger et al. (2005) ( $P$ [Yate's] = 0.004). Captive-bred Puaiohi built their nests of ferns (Sticherus owhyensis, Dicranopteris linearis), pa'iniu (Astelia argyrocoma), 'ōhi'a hā (Syzygium sandwicensis) and 'ōhi'a leaves, and mosses. All cliff nests in our study were qualitatively similar in construction and site characteristics to those made by wild Puaiohi.

Nest building and subsequent days of inactivity lasted between 7 and 17 days (mean \pm SE $=$ $10.8 \pm 3.7$ days; $n=9$ ). Females were the primary nest builders, making 222 of 225 (98.7\%) nest visits, and only females developed brood patches, incubated, and brooded young. Mean clutch size was $2.0 \pm 0.4$ eggs $(n=16)$. One nest contained one egg and another nest contained three eggs; these are the first observations of Puaiohi nests containing other than two eggs (Table 1). Egg viability, measured as the percentage of eggs that hatched out of the total number of eggs that were laid and incubated to term (e.g., excluding abandoned or depredated eggs), was $100 \%$ ( $n=22$ eggs in 11 clutches). Incubation lasted $12-14$ days (13.2 \pm 0.8 days; $n=$ 5). Males were observed feeding adult females on the nest on five occasions. Nestlings fledged 16-23 days after hatching ( $18.3 \pm 1.9$ days; $n=10$

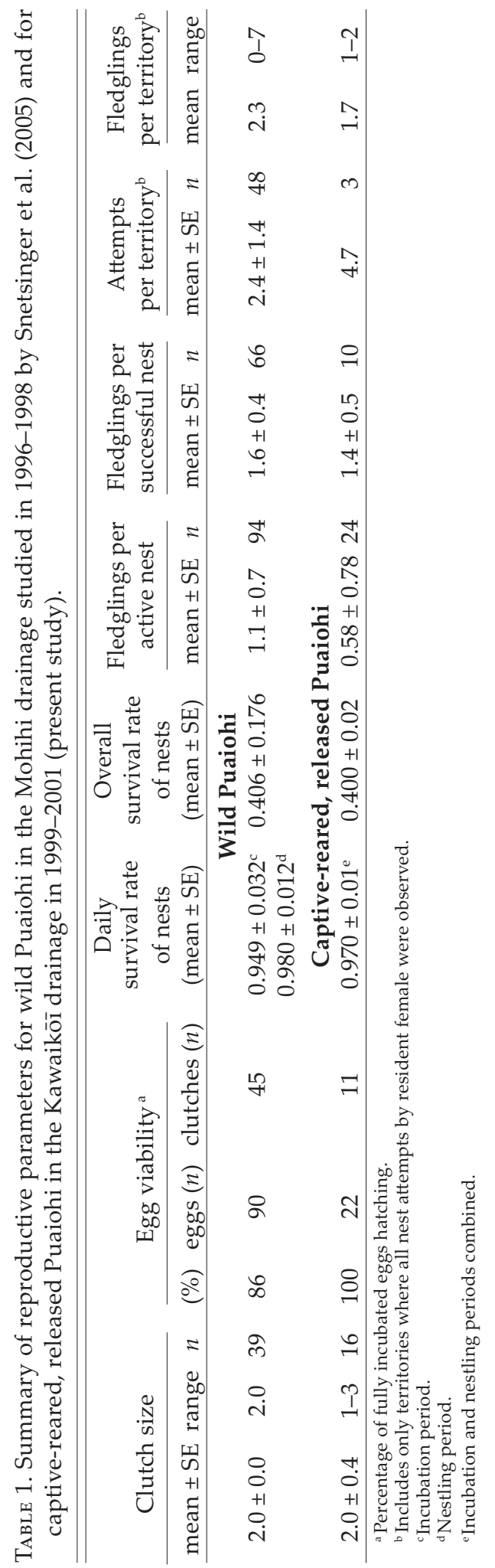


nests). Incubation and nestling periods did not differ from those documented for wild Puaiohi (13.5 \pm 0.6 days and $18.3 \pm 1.7$ days, respectively; Snetsinger et al. 2005).

Nesting success and causes of nest failure.-Of 24 active nests with known fates, $42 \%$ fledged at least one young, and $38 \%$ were depredated (Table 2). One nest each $(4 \%)$ failed because of inclement weather and death of the female on the nest for unknown reasons. Daily nest survival rate of the released population was $0.97 \pm 0.01$, and the probability of a nest surviving for the entire 31.6-day nesting cycle was $0.40 \pm 0.02 ; n=$ 547.5 exposure days and 27 nests). These daily and overall nest survival rates were remarkably similar to those of wild birds in the Mohihi drainage studied in 1995-1998 (Table 1).

Mean number of fledglings per active nest of captive-bred birds was $0.58 \pm 0.78(n=24)$, and mean number of fledglings per successful nest was $1.4 \pm 0.5$ (range: $1-2 ; n=10$ ). In comparison, wild birds fledged $1.1 \pm 0.7$ birds per active nest and $1.6 \pm 0.4$ fledglings per successful nest (Snetsinger et al. 2005; Table 1). Six of seven $(85.7 \%)$ fledglings monitored in 1999 survived at least two weeks postfledging; no comparable data are available for wild birds.

We confirmed rat predation as the cause of nest failure in four of the nine depredated nests, and suspected it to be the cause in four others. Rats also depredated the adult females at two of these nests. Nonetheless, there appears to be no difference in the probability of nest success at nests protected with bait and traps compared with unprotected nests (Table 2; we refrain from testing statistically because of necessary biases in assigning treatment groups, that is, all unprotected nests were $<5 \mathrm{~m}$ from water; see above). These results are in contrast to an earlier study of wild birds (Snetsinger et al. 2005); however, in that study as in ours, nests were not randomly assigned to treatment groups, so that the stage when found, terrain, and nest height were confounding factors.

Excluding predation events, nine nestlings in eight nests died. One death was likely attributable to exposure during heavy rain, and two resulted from the death of the brooding mother. We observed five cases of apparent brood reduction, in which one to two young died and their nest mate(s) survived. Two of these chicks (from two separate nests) were recovered and had apparently starved (no signs of trauma); they were also the smaller of the two chicks in their broods. The other four chicks (from three nests) disappeared between 2.5 and 10 days of age.

Renesting and seasonal fecundity.-Captivereared Puaiohi females readily renested after both failed and successful nesting attempts. When females were successful, they often reused the previous nest site (six of eight renests by six females), but no female reused the nest site where the previous nesting attempt had failed (zero of seven renests by six females). The time between nest failure or fledging and initiation of the successive clutch for five different females averaged $15.6 \pm 11.8$ days (range: $5-47 ; n=12$ ). One female began constructing her next nest even before the young from her previous nest had fledged, and laid the first egg of the next clutch only five days after they fledged. At least two females were confirmed

TABLE 2. Nest fates of 24 active, known-fate nests of 10 captive-bred female Puaiohi, 1999-2001, Kawaikōī Stream Drainage, Alaka'i Swamp, Kaua 'i. "Protected nests" were protected by bait stations and snap-traps from rodent predators as described in text.

\begin{tabular}{lccc}
\hline \hline & $\begin{array}{c}\text { Protected } \\
\text { nests }\end{array}$ & $\begin{array}{c}\text { Unprotected } \\
\text { nests }\end{array}$ & Total \\
\hline Abandoned during incubation & 1 & 1 & 2 \\
Failed due to inclement weather & 1 & 0 & 1 \\
Death of adult female & 0 & 1 & 1 \\
Predation by rat a & 4 & 4 & 8 \\
Predation by unknown predator & 1 & 0 & 1 \\
Unknown cause of failure & 0 & 1 & 1 \\
Successful & 5 & 5 & 10 \\
Total & 12 & 12 & 24 \\
\hline
\end{tabular}

${ }^{a}$ Includes two nests at which the adult female and nest were depredated by rats. 
to have double-brooded and then attempted third broods. Pairs remained together through successive nesting attempts in a given year, but no pairs remained together between years (it is unknown whether this was attributable to mortality or to mate-switching).

In 1999, we documented all nesting attempts for the season for six pairs. The breeding season of three of these pairs was cut short by the death of the adult females. The three pairs that survived the entire breeding season attempted three, five, and six nests, respectively, and fledged an average of 1.7 young (range: 1-2) over the course of the season. In comparison, wild female Puaiohi studied over three breeding seasons (1996-1998) attempted an average of 2.4 nests season ${ }^{-1}$, and fledged 2.3 young territory ${ }^{-1}$ (Table 1 ).

\section{Discussion}

The present study marks the first release of a captive-reared endangered passerine bird in Hawaii, and is a model for reintroduction programs for other endangered passerines. Survivorship of reintroduced birds was remarkably high, all monitored captive-bred Puaiohi readily paired with wild and other captive-bred birds, and at least eight females successfully fledged young in their first season after release. This provides an important success story for an avifauna beleaguered by multiple limiting factors, poorly known biology, limited recovery dollars, and a worldwide reputation as a lost cause.

Breeding biology. - The breeding biology of captive-bred, released Puaiohi showed few apparent differences from that of wild birds. Clutch size, egg viability, and incubation and brooding behavior did not differ between captive-bred and wild birds. However, although cliff-side nest sites along streams appear to be the preferred nesting locations in both captivebred and wild Puaiohi, captive-bred birds built a significantly greater proportion of their nests in trees. This may reflect imprinting in captivity or limited availability of suitable cliff-face nest sites in the release drainage. Most notably, daily and overall survival rates of nests were comparable between the two populations, $\sim 40 \%$ of active nests fledging young in both populations. Both wild and released females renested readily after both nest failure and nest success throughout the breeding season. However, the wild population experienced wide fluctuations in productivity among the years studied, because of a shortened breeding season and increased predation resulting from drought in 1998 related to El Niño-Southern Oscillation (ENSO). When only "normal" years of data are considered, fecundity of the released population appears to be much lower than that of the wild birds (e.g., 0.58 young per nest attempt in the released population, vs. 1.4-1.7 young per nest attempt in the wild population; table 2 in Snetsinger et al. 2005).

This study marked the first observation of polygyny in Puaiohi; of 30 wild nesting pairs in three seasons, all were monogamously mated (Snetsinger et al. 2005). Polygynous mating had a cost for females, who increased their feeding trips, likely in response to lower feeding rates by the male; renested more slowly after fledging young; and fledged fewer young per successful nest than their monogamously mated counterparts (USGS unpubl. data). In the present study, the pool of released birds was femalebiased (1.6:1); furthermore, a higher proportion of males than of females dispersed out of the release drainage (Tweed et al. 2003). A few females, therefore, would have to have undergone a potentially hazardous dispersal, forgone breeding, or accepted the polygynous mating.

Food limitation and brood reduction.-One nestling in each of two nests was found dead of starvation, and four nestlings in four other nests disappeared, though their nest mate(s) continued to thrive. Notably, brood reduction occurred only in nests of polygynously mated females. We interpret the disappearance of single young from two-egg clutches to suggest that competition may occur between nest mates for limited food resources in this population. In support of this idea, in the wild population, Puaiohi fledge nearly two young per nest in years of normal rainfall, but they average only one fledgling per nest in drought years (Snetsinger et al. 2005).

Disease.-Avian malaria and avian pox (Poxvirus avium) have devastated populations of most native forest birds at low elevations throughout the main Hawaiian Islands (van Riper et al. 1986). The Alaka'i Plateau, at only $\sim 1,200$ m elevation, is unfortunately not immune. The prevalence of malaria is $\sim 10 \%$ in forest birds at Kōke'e Park and Koaie Stream (USGS unpubl. data). One of five wild Puaiohi that have been tested showed antibodies to avian malaria (Atkinson et al. 2001), but much further research on their susceptibility remains to be done. 
Avian pox and avian malaria have not noticeably affected released birds. However, extremely dry conditions during the 1999 Puaiohi breeding season decreased local populations of mosquitoes (Culex quinquefasciatus), the main vector of avian malaria (USGS unpubl. data). We are uncertain how the Puaiohi population will be affected by disease in wetter years, when mosquito populations (and, thus, disease transmission) are higher.

Predation.-Predation was the single greatest cause of nest loss in both the reintroduced and wild populations (Snetsinger et al. 2005, present study). The Alaka'i Swamp is home to several potential predators of Puaiohi and their chicks: black rats (Rattus rattus), Polynesian rats (R. exulans), Barn Owls (Tyto alba), Pueo, and feral cats (Felis catus) (all but Pueo are introduced). Predation occurred most often during the nestling stage, when nests are more conspicuous because of nestling begging calls, increased visitation by adults, and the scent of nestlings. Predation is a strong selective force on parental and chick behavior at nests, usually leading to more cryptic behavior of parents and young (Briskie et al. 1999, Martin et al. 2000), but Puaiohi do not have an evolutionary history with mammalian predators. Thus, Puaiohi would not be expected to have necessarily maintained cryptic behaviors at the nest and may be particularly vulnerable to nest predation.

The relatively high seasonal fecundity of Puaiohi, and their ability to renest repeatedly ( $\leq 4.9$ fledglings per territory in a good year; Snetsinger et al. 2005) may allow populations to withstand a certain level of nest predation. More troubling, however, was the loss of three breeding females on nests during the present study. The three-year study of the wild population (including 98 active nesting attempts) documented only one female depredated on the nest. We are unsure whether this difference is attributable to naiveté of captive-bred females, nest-site selection, habitat-environmental conditions, local predator abundance, annual fluctuations, or chance. Regardless, the loss of adult females could be a significant obstacle to recovery efforts.

We conclude that introduced mammalian predators are a serious problem for Puaiohi recovery, at least in the northwestern Alaka'i Swamp, and there is need for a cost-effective management technique that can be applied at an ecosystem level. Our nest-by-nest approach to protecting Puaiohi and their young from predation using traps and poison bait was not effective. Although rodent eradication campaigns have been conducted with good success on small oceanic islands, control on large land masses is more problematic (Courchamp et al. 2003). Research is currently looking into the effects of hand and aerial broadcast of rodenticides as an ecosystem management tool for controlling introduced rodents in Hawaii.

Conclusion.-The most promising outcome from our monitoring efforts was that captivebred Puaiohi successfully paired and nested in the wild within the first breeding season. The seven fledglings produced in the 1999 breeding season are part of the first generation of Puaiohi in the Kawaikōì drainage. Although nest predation was common, $40 \%$ of nests fledged young, and most of the fledglings appeared to survive to two weeks postfledging. However, despite these short-term successes, the breeding population in the Kawaikōī appears to have dwindled. Field surveys in May and June 2002 (>90 h of surveys of $8.9 \mathrm{~km}$ of stream valley) were able to locate only seven birds remaining in the Kawaikōì drainage, including one nesting pair with four fledglings from two separate broods and one unmated adult (USGS unpubl. data). Although continued releases at one site are not always necessary (Armstrong and Ewen 2001), this population might have benefited from additional releases, especially in light of the high dispersal rates of males out of the target drainage (Tweed et al. 2003). The number of birds released in a reintroduction program strongly correlates with release success (Green 1997, Wolf et al. 1998), and 34 birds may not have been sufficient to allow the population to weather chance demographic events. Habitat quality (including predator abundance), however, may be an even more important determinant of reintroduction success, particularly for long-term persistence (Armstrong and McLean 1996, Wolf et al. 1998).

Ultimately, the solution for halting the decline of most endangered species is preventing the loss and degradation of habitat. Captive breeding and reintroduction are tools that allow us to rescue very rare species from the brink of extinction, thereby "buying time" until limiting factors can be mitigated and habitat restored. The observations of breeding behavior and success of reintroduced Puaiohi indicate the feasibility of this approach for endangered passerines, while 
highlighting the importance of maintaining and restoring safe habitat for their reintroduction.

\section{Acknowledgments}

We thank the following individuals for contributing countless hours of grueling field work to obtain the breeding data presented here: N. Gregory, C. Erwin, B. Schmeling, and A. Erichsen; without their assistance, this work would have been impossible. We acknowledge the Zoological Society of San Diego-Keauhou Bird Conservation Center staff for their groundbreaking efforts toward breeding, rearing, and releasing Puaiohi into the wild, especially C. Kuehler, P. Oesterle, A. T. Goltz, and K. Whittaker. We thank the Hawaii Division of Forestry and Wildlife for continual support and permission to work on their land. M. Erikson and M. Hookano of the Kōke'e Natural History Museum provided logistical support. We owe special thanks to T. Snetsinger and C. Herrmann for their guidance, access to unpublished data, and for building the foundation of Puaiohi recovery efforts through their research on the wild population, and to S. Fancy, K. Rosa, T. Telfer, R. Smith, J. Jacobi, C. Kuehler, E. Petteys, and the other members of the original Puaiohi working group, who conceived of the reintroduction project and brought it to fruition. Funding for this work was provided by the USGS Pacific Island Ecosystems Research Center, the U.S. Fish and Wildlife Service, and the Hawaii Division of Forestry and Wildlife. Support for captive breeding and releases was provided by the Peregrine Fund, Zoological Society of San Diego, Club 300 of Sweden, The G. N. Wilcox Foundation, the Anne Sinclair Foundation of the Hawaii Community Foundation, the Geraldine Dodge foundation, the Kaytee Avian Foundation, and the Wallace Research Foundation. Any use of trade, product, or firm names in this publication is for descriptive purposes only and does not imply endorsement by the U.S. Government.

\section{Literature Cited}

Armstrong, D. P., I. Castro, J. C. Alleey, B. Feenstra, and J. K. Perrott. 1999. Mortality and behaviour of Hihi, an endangered New Zealand honeyeater, in the establishment phase following translocation. Biological Conservation 89:329-339.
Armstrong, D. P., R. S. Davidson, W. J. Dimond, J. K. Perrott, I. Castro, J. G. Ewen, R. Griffiths, and J. Taylor. 2002. Population dynamics of reintroduced forest birds on New Zealand islands. Journal of Biogeography 29:609-621.

Armstrong, D. P., And J. G. Ewen. 2001. Assessing the value of follow-up translocations: A case study using New Zealand robins. Biological Conservation 101:239-247.

Armstrong, D. P., and I. G. McLean. 1996. New Zealand translocations: Theory and practice. Pacific Conservation Biology 2:39-54.

Atkinson, C. T., J. K. Lease, B. M. Drake, and N. P. Shema. 2001. Pathogenicity, serological responses, and diagnosis of experimental and natural malarial infections in native Hawaiian thrushes. Condor 103:209-218.

Briskie, J., P. R. Martin, and T. E. Martin. 1999. Nest predation and the evolution of nestling begging calls. Proceedings of the Royal Society of London, Series B 266:2153-2159.

Courchamp, F., J.-L. Chapuis, and M. Pascal. 2003. Mammal invaders on islands: Impact, control, and control impact. Biological Reviews 78:347-383.

Fancy, S. G., J. T. Nelson, P. Harrity, J. Kuhn, M. Kuhn, C. Kuehler, and J. G. Giffin. 2001. Reintroduction and translocation of 'Ōma'o: A comparison of methods. Pages 347-353 in Evolution, Ecology, Conservation, and Management of Hawaiian Birds: A Vanishing Avifauna (J. M. Scott, S. Conant, and C. van Riper III, Eds.). Studies in Avian Biology, no. 22.

Foster, J. T., E. J. Tweed, R. J. Camp, B. L. Woodworth, C. D. Adler, and T. Telfer. 2004. Long-term population changes of native and introduced birds in the Alaka'i Swamp, Kaua 'i. Conservation Biology 18:716-725.

Giambelluca, T. W., M. A. Nullet, and T. A. Schroeder. 1986. Rainfall Atlas of Hawaii. Department of Natural Resources, Division of Water and Land Development, State of Hawaii, report no. R76.

Green, R. E. 1997. The influence of numbers released on the outcome of attempts to introduce exotic bird species to New Zealand. Journal of Animal Ecology 66:25-35.

Kuehler, C., A. Lieberman, P. Oesterle, T. Powers, M. Kuhn, J. Kuhn, J. Nelson, T. Snetsinger, C. Herrmann, P. Harrity, and OTHERS. 2000. Development of restoration 
techniques for Hawaiian thrushes: Collection of wild eggs, artificial incubation, hand-rearing, captive-breeding, and reintroduction to the wild. Zoo Biology 19: 263-277.

Martin, T. E., J. ScotT, And C. Menge. 2000. Nest predation increases with parental activity: Separating nest site and parental activity effects. Proceedings of the Royal Society of London, Series B 267:2287-2293.

Mayfield, H. F. 1961. Nesting success calculated from exposure. Wilson Bulletin 73:255-261.

Mayfield, H. F. 1975. Suggestions for calculating nest success. Wilson Bulletin 87:456-466.

Nelson, J. T., B. L. Woodworth, S. G. Fancy, G. D. Lindsey, And E. J. Tweed. 2002. Effectiveness of rodent control and monitoring techniques for a montane rainforest. Wildlife Society Bulletin 30:82-92.

Pratt, H. D. 1982. Relationships and speciation of the Hawaiian thrushes. Living Bird 19:73-90.

Pratt, H. D. 1994. Avifaunal change in the Hawaiian islands, 1893-1993. Pages 103-118 in A Century of Avifaunal Change in Western North America (J. R. Jehl, Jr., and N. K. Johnson, Eds.). Studies in Avian Biology, no. 15.

RAlph, C. J., AND C. VAN Riper III. 1985. Historical and current factors affecting Hawaiian native birds. Pages $7-42$ in Bird Conservation, vol. 2 (S. A. Temple, Ed.). University of Wisconsin Press, Madison.

Rappole, J. H., and A. R. Tipton. 1991. New harness design for attachment of radiotransmitters to small passerines. Journal of Field Ornithology 62:335-337.

Reynolds, M. H., And T. J. Snetsinger. 2001. The Hawai'i rare bird search 1994-1996. Pages 133-143 in Evolution, Ecology, Conservation, and Management of Hawaiian Birds: A Vanishing Avifauna (J. M. Scott, S. Conant, and C. van Riper III, Eds.). Studies in Avian Biology, no. 22.

Rudolph, D. C., R. N. Conner, D. K. Carrie, AND R. R. Schaefer. 1992. Experimental reintroduction of Red-Cockaded Woodpeckers. Auk 109:914-916.

SAnZ, V., AND A. Grajal. 1998. Successful reintroduction of captive-raised Yellow-shouldered Amazon parrots on Margarita Island, Venezuela. Conservation Biology 12:430-441.

Scott, J. M., AND J. W. Carpenter. 1987. Release of captive-reared or translocated endangered birds: What do we need to know? Auk 104:544-545.

Scott, J. M., S. Conant, and C. van Riper III. 2001. Introduction. Pages 1-12 in Evolution, Ecology, Conservation, and Management of Hawaiian Birds: A Vanishing Avifauna (J. M. Scott, S. Conant, and C. van Riper III, Eds.). Studies in Avian Biology, no. 22.

Shaffer, T. L. 2004. A unified approach to analyzing nest success. Auk 121:526-540.

Snetsinger, T. J., C. M. Herrmann, D. E. Holmes, C. D. Hayward, and S. G. Fancy. 2005. Breeding ecology of the Puaiohi (Myadestes palmeri). Wilson Bulletin 117: 72-84.

Snetsinger, T. J., K. M. Wakelee, and S. G. FANCY. 1999. Puaiohi (Myadestes palmeri). In The Birds of North America, no. 461 (A. Poole and F. Gill, Eds.). Birds of North America, Philadelphia.

Toвin, M. E. 1992. Rodent damage in Hawaiian macadamia orchards. Proceedings of the Vertebrate Pest Conference 15:272-276.

Tweed, E. J., J. T. Foster, B. L. Woodworth, P. Oesterle, C. Kuehler, A. A. Lieberman, A. T. Powers, K. Whitaker, W. B. Monahan, J. Kellerman, and T. Telfer. 2003. Survival, dispersal, and home-range establishment of reintroduced captive-bred Puaiohi, Myadestes palmeri. Biological Conservation 111:1-9.

U.S. Fish and Wildlife Service. 2003. Draft revised recovery plan for Hawaiian forest birds. U.S. Fish and Wildlife Service, Region 1, Portland, Oregon.

van Riper, C., III, AND J. M. Scott. 2001. Limiting factors affecting Hawaiian native birds. Pages 221-233 in Evolution, Ecology, Conservation, and Management of Hawaiian Birds: A Vanishing Avifauna (J. M. Scott, S. Conant, and C. van Riper III, Eds.). Studies in Avian Biology, no. 22.

van Riper, C., III, S. G. van Riper, M. L. Goff, AND M. LAIRD. 1986. The epizootiology and ecological significance of malaria in Hawaiian land birds. Ecological Monographs 56: 327-344.

Wolf, C. M., T. Garland, Jr., and B. Griffith. 1998. Predictors of avian and mammalian translocation success: Reanalysis with phylogenetically independent contrasts. Biological Conservation 86:243-255.

Associate Editor: N. S. Sodhi 